\title{
Rapidly Progressive Epstein-Barr Virus-associated Lymphoproliferative Disorder Unpredictable by Weekly Viral Load Monitoring
}

\author{
Shihoko Wakabayashi ${ }^{1,2}$, Kazuteru Ohashi ${ }^{1}$, Ryo Hanajiri ${ }^{1}$, Takeshi Kobayashi ${ }^{1}$, \\ Takuya Yamashita ${ }^{1}$, Hideki Akiyama ${ }^{1}$ and Hisashi Sakamaki ${ }^{1}$
}

\begin{abstract}
We report a case of Epstein-Barr virus (EBV)-associated lymphoproliferative disease (LPD) following unrelated bone marrow transplantation (UBMT) for severe aplastic anemia treated with a conditioning regimen that included anti-thymocyte globulin (ATG). The patient showed signs of EBV reactivation as early as 34 days after UBMT. Our weekly schedule for EBV monitoring failed to trace rapid changes in EBV viral load and the patient eventually developed EBV-LPD. However, early intervention with monoclonal antibody against CD20, rituximab, stopped the further progression of EBV-LPD. As several recent reports have suggested, the safety and efficacy of rituximab treatment for EBV-LPD is supported by our limited experience with post transplant EBV-LPD.
\end{abstract}

Key words: aplastic anemia, unrelated bone marrow transplantation, anti-thymocyte globulin, Epstein-Barr virus-associated lymphoproliferative disorders, rituximab

(Inter Med 49: 931-935, 2010)

(DOI: 10.2169/internalmedicine.49.3114)

\section{Introduction}

Epstein-Barr virus-associated lymphoproliferative disorder (EBV-LPD) is a rare but lethal complication in the setting of allogeneic hematopoietic stem cell transplantation (HSCT) (1). The overall cumulative incidence of EBV-LPD is low, occurring in approximately $1-3 \%$ of allogeneic HSCT, and most patients receive the diagnosis within the initial 6 months after transplantation. The major risk factor for EBV-LPD is the use of in vivo T-cell depletion with antithymocyte globulin (ATG) for prophylaxis of acute graftversus-host disease (GVHD), or reduced intensity conditioning regimens $(2,3)$. EBV-LPD caused by the outgrowth of latently infected B cells under the absence of competent immune surveillance systems as a consequence of ATG treatment. Because of the rapid clinical course of EBV-LPD, immediate treatment is crucial to reduce mortality $(4,5)$. Recently, it has been suggested that frequent monitoring of
EBV-DNA load by quantitative real-time PCR makes early treatment possible, and there are several reports supporting this strategy $(6,7)$. We report a case of EBV-LPD following unrelated allogeneic bone marrow transplantation using a conditioning regimen including ATG. Our weekly schedule for EBV monitoring failed to predict the onset of EBV-LPD, but it was successfully treated with a single dose of rituximab.

\section{Case Report}

A 23-year-old man was diagnosed with severe aplastic anemia (SAA) in July 2006. The administration of cyclosporine was ineffective, and he became dependent on regular and frequent red blood cell transfusions. The patient was subsequently admitted to our hospital for unrelated bone marrow transplantation (UBMT) in August 2008. The physical findings included severe conjunctival anemia and several oral mucosal hematomas, but no superficial lympha-

${ }^{1}$ Hematology Division, Tokyo Metropolitan Cancer and Infectious Diseases Center, Komagome Hospital, Tokyo and ${ }^{2}$ Hematology Division, Tokyo Medical and Dental University, Tokyo

Received for publication November 6, 2009; Accepted for publication January 21, 2010

Correspondence to Dr. Kazuteru Ohashi, k.ohashi@cick.jp 
A.

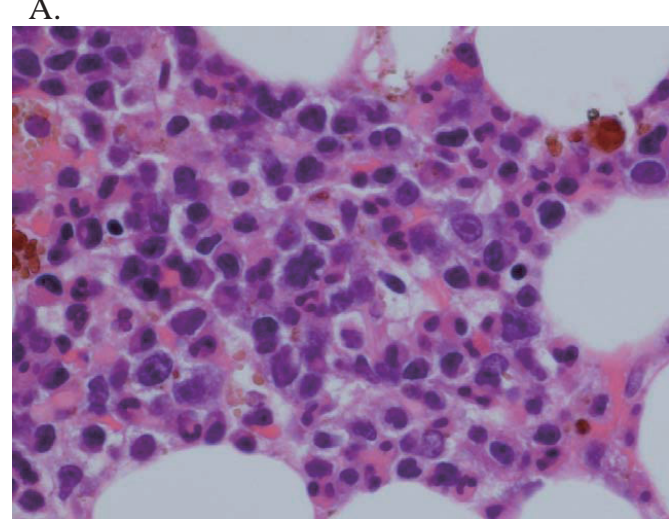

C.

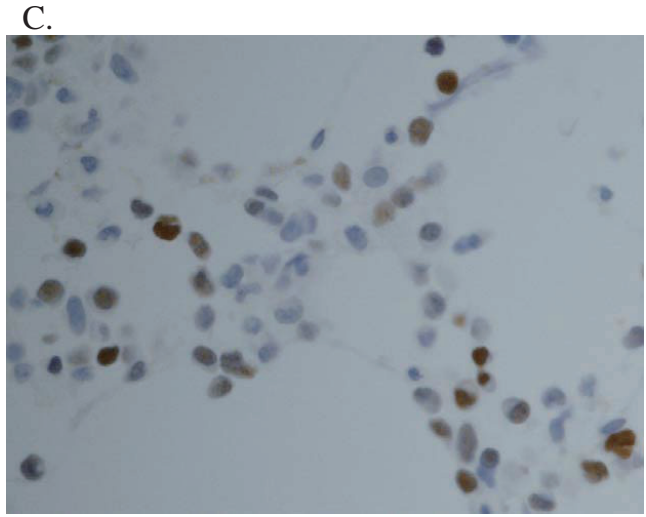

B.

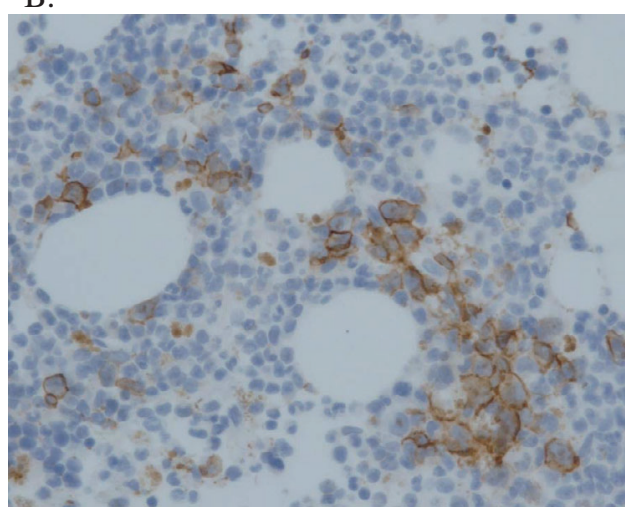

Figure 1. Photomicrographs of specimens from the bone marrow aspiration. Bone marrow aspiration specimen shows an increase in $\mathrm{CD20}$ positive lymphocytes positive for Epstein-Barr virus (EBV)-encoded mRNA (EBER) by in situ hybridization. (A) Hematoxylin and Eosin staining, (B) CD20 immuno-staining, (C) in situ hybridization for EBER.

denopathy, hepatomegaly, or splenomegaly were noted. The laboratory findings demonstrated a white blood cell (WBC) count of $1,400 / \mu \mathrm{L}$, neutrophil count of $96 / \mu \mathrm{L}$, red blood cell count of $254 \times 10^{4} / \mu \mathrm{L}$, hemoglobin $(\mathrm{Hb})$ of $7.2 \mathrm{~g} / \mathrm{dL}$, hematocrit of $20.7 \%$, platelet (Plt) count of $1.0 \times 10^{4} / \mu \mathrm{L}$, reticulocytes $1 \%$, and serum ferritin level of $2,269 \mathrm{ng} / \mathrm{mL}$. A coagulation test was within normal limits. Bone marrow aspiration revealed severe hypo-cellular bone marrow $\left(0.1 \times 10^{4} /\right.$ $\mu \mathrm{L}$ ) with no morphological dysplasia.

In February 2009, the patient underwent BMT from an HLA identical unrelated donor (total nuclear cells $3.2 \times 10^{8}$ / $\mathrm{kg}$ ). In our institution, patients with SAA usually receive total lymphoid irradiation (TLI) and cyclophosphamide as a conditioning regimen. But, this time, the patient was conditioned with fludarabine $\left(30 \mathrm{mg} / \mathrm{m}^{2} /\right.$ day, day -10 to -5$)$, cyclophosphamide $\left(60 \mathrm{mg} / \mathrm{m}^{2} / \mathrm{day}\right.$, day -6 to -5$)$ and thymoglobulin (rabbit, $2.5 \mathrm{mg} / \mathrm{kg} / \mathrm{day}$, day -4 to -1 ). This was mainly due to the unavailability of irradiation therapy equipment in the facility. The prophylaxis for acute graft-versushost disease (GVHD) consisted of short-course methotrexate $\left(10,7\right.$, and $7 \mathrm{mg} / \mathrm{m}^{2}$ on days 1,3 , and 6 , respectively) and cyclosporine. Although the engraftment was observed 14 days after UBMT, the patient developed persistent high fever from day 33, which was refractory to antibiotics and antiviral agents. Moreover, his liver function tests worsened, including a total bilirubin of $1.9 \mathrm{mg} / \mathrm{dL}$, asparatate aminotransferase of $408 \mathrm{IU} / \mathrm{L}$, alanine aminotransferase of 577 IU/L, $\gamma$-glutamyltranspeptidase of 779 IU/L, and alkaline phosphatase of $848 \mathrm{IU} / \mathrm{L}$. In accordance with his liver dysfunction, the patient developed pancytopenia (WBC $4,200 / \mu \mathrm{L}, \mathrm{Hb} 8.4 \mathrm{~g} / \mathrm{dL}$, Plt $\left.1.0 \times 10^{4} / \mu \mathrm{L}\right)$. Bone marrow aspiration revealed an increased number of lymphocytes, but no apparent hemophagocytic findings (Fig. 1A). Serum lactate dehydrogenase (1,823 IU/L) and ferritin $(29,770 \mathrm{ng} / \mathrm{mL})$ levels were also significantly elevated. A computed tomography scan of the abdomen obtained at this time verified splenomegaly.

Based on these clinical signs and the use of ATG in the conditioning regimen, EBV-LPD was highly suspected. Even though the result of plasma EBV-DNA load was not available at the time, a single dose of rituximab $\left(375 \mathrm{mg} / \mathrm{m}^{2}\right)$ was administered on day 42. On the following day, day 43, the patient became afebrile and hepatic dysfunction and ferritin level dramatically improved (Fig. 2). The belated result of peripheral plasma EBV-DNA $\left(2.3 \times 10^{6}\right.$ copies/ $\mu$ g DNA) and pathological examination from bone marrow aspiration (demonstrating an increase in CD20 positive lymphocytes positive for EBV-encoded mRNA (EBER) by in situ hybridization (Fig. 1B and $\mathrm{C}$ )) confirmed the diagnosis of EBV-LPD. After the single administration of rituximab, the EBV-LPD stabilized with a low EBV-DNA load of 100 copies/Mg DNA level, as shown in Fig. 3. 


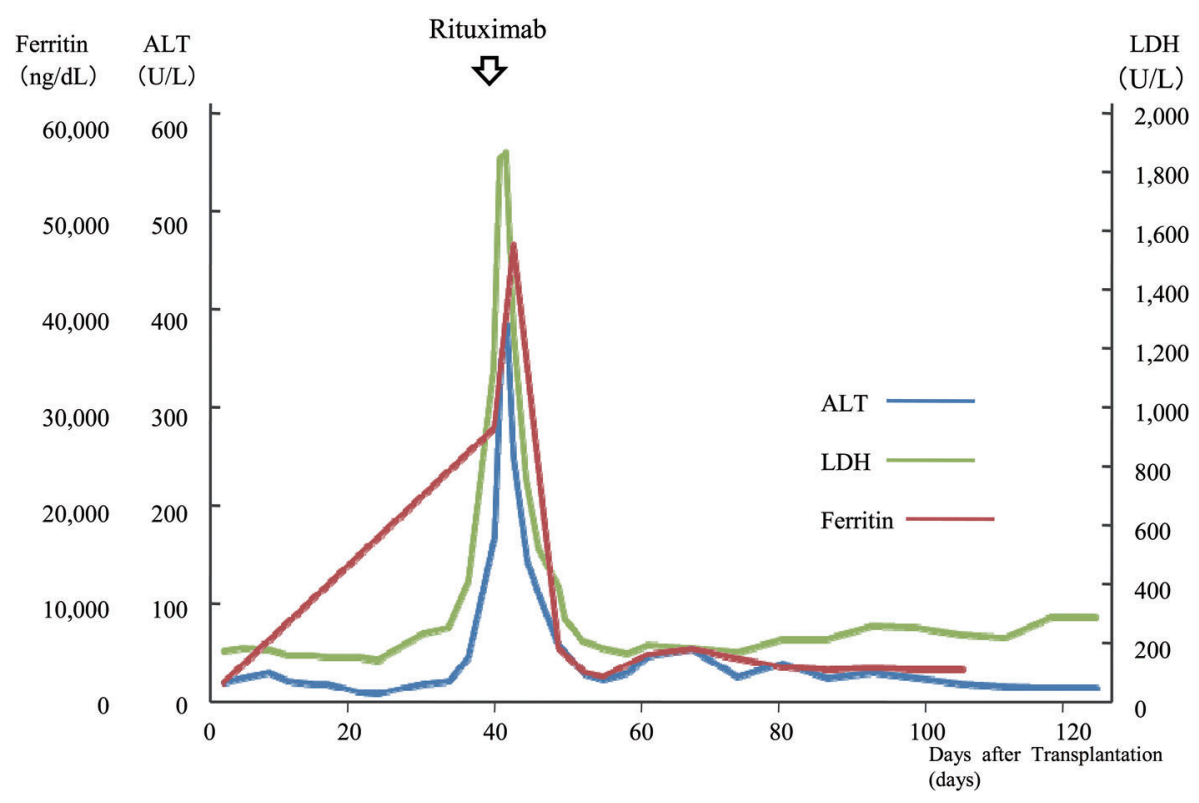

Figure 2. Serial changes in ALT, LDH and ferritin levels.

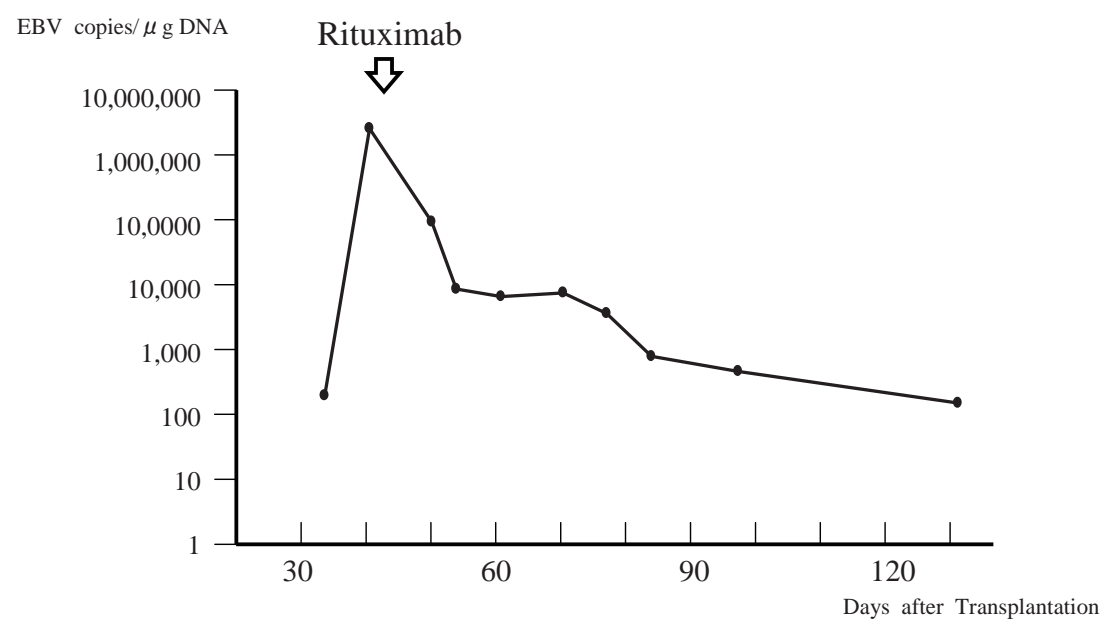

Figure 3. Serial changes in EBV DNA levels. RQ-PCR assay was performed with the aid of TaqMan technology (PE Biosystems, Foster City, CA, USA). Primers and detection probes were as described previously. Assay was commercially available and actually performed at SRL Co., Ltd., Tokyo, Japan.

\section{Discussion}

In Europe and the United States, ATG has been used for more than 30 years as the principle prophylactic agent against GVHD, and numerous studies have confirmed its efficacy in reducing the incidence and severity of subsequent GVHD. By contrast, ATG has only recently been used in the setting of allogeneic transplantation in Japan (since December 2008). However, this medication has been commonly associated with several complications such as ongoing immune deficiency and opportunistic infections, including an increased risk of EBV reactivation (2). EBV-LPD is lethal, especially in allogeneic HSCT, and immediate treatment based on early diagnosis is crucial for patient survival. EBV-LPD could not be effectively controlled by the dose reduction or discontinuation of immunosuppressants alone. An effective therapeutic option can be provided by EBV-specific cytotoxic $\mathrm{T}$ lymphocytes with donor lymphocytes infusion (DLI). However, the largest flaw of this strategy was the lack of ready availability especially in the setting of UBMT. Moreover, DLI could be associated with an increased risk of severe GVHD. Recent studies have demonstrated the safety and efficacy of rituximab as a treatment for EBVLPD (5, 8-10). Preemptive administration of rituximab before obvious EBV-LPD develops has received significant attention. When the viral load exceeds 1,000 DNA copies $/ 10^{5}$ cells, intervention with rituximab should be initiated promptly. This strategy appears to be highly effective in controlling viral proliferation and avoiding subsequent disease manifestation $(2,6,11)$, although other reports have described different threshold values (Table 1) $(7,12-14)$. 
Table 1. Studies Reported about the Preemptive Treatment with Rituximab in LPD

\begin{tabular}{|c|c|c|c|c|c|c|}
\hline \multicolumn{2}{|r|}{ Patients population } & \multirow{2}{*}{$\begin{array}{l}\text { PCR assay } \\
\text { Threshold }\end{array}$} & \multicolumn{3}{|c|}{ Preemptive treatment } & \multirow[t]{2}{*}{ Reference } \\
\hline $\mathrm{N}$ & Patients group & & $\mathrm{N}$ & Therapy & Cure $(\%)$ & \\
\hline 77 & HLA-mismatched, unrelated donor & $1,000 \mathrm{gEq} / \mathrm{mL}$ & 11 & Rituximab once & 93 & 2) \\
\hline 49 & T-cell depleted & $1,000 \mathrm{gEq} / \mathrm{mL}$ & 15 & Rituximab once & 91 & 6) \\
\hline NA & T-cell depleted, ATG & $10^{4} \mathrm{gEq} / 10^{5} \mathrm{PBMCs}$ & 3 & Rituximab once & 100 & 7) \\
\hline NA & T-cell depleted, HLA-mismatched & $10^{4} \mathrm{gEq} / 10^{5} \mathrm{PBMCs}$ & 2 & Rituximab, DLI & 100 & 7) \\
\hline NA & T-cell depleted & $4000 \mathrm{gEq} / \mu \mathrm{gDNA}$ & 2 & Rituximab, CTLs & 100 & 8) \\
\hline 115 & $\begin{array}{l}\text { T-cell depleted, ATG, } \\
\text { HLA-mismatched, unrelated donor }\end{array}$ & $40,000 \mathrm{gEq} / \mathrm{mL}$ & 19 & Rituximab & 89 & 13) \\
\hline 80 & HLA-mismatched, unrelated donor & $20,000 \mathrm{gEq} / 10^{5} \mathrm{PBMCs}$ & 9 & Rituximab & 89 & 14) \\
\hline
\end{tabular}

Abbreviations; Cure: no clinical sign of the recurrence of LPD, CTLs: EBV-specific cytotoxic T lymphocytes, DLI: donor leukocyte infusions, ATG: anti thymocyteglobulin, PCR: polymerase chain reaction, gEq: genome equivalents, PBMCs: peripheral blood mononuclear cells, N: number of patients, NA: not available.

Certain obstacles which are inherent in performing EBV viral load monitoring need to be overcome, however. For example, the optimal EBV monitoring schedule is unclear at this time. In the present case, we examined EBV viral load every 7 to 10 days. The actual number of copies of EBV at day 34, 1 day after the onset of pyrexia, was 200 copies/ $\mu \mathrm{g}$ DNA, but it was increased by more than 100,000 fold by day 42. Thus, our screening interval may not be adequate to trace rapid changes in the EBV viral load. Rather, more flexible monitoring is necessary, especially on the occasion of a clinical sign such as pyrexia, in order to administer prompt treatment with rituximab. In addition, it usually takes several days until test results are available. Since some patients can become overwhelmed by EBV within a single day, it is not possible to withhold treatment until test results become available. Thus, collaboration between the clinical front and the laboratory is essential in order to ensure a prompt response on the same day. Finally, most of the previously reported series dealt with a limited number of patients with EBV-LPD, therefore, prospective multicenter trials are required to validate the optimal prophylaxis and efficacy of preemptive rituximab therapy, based on EBV DNA load monitoring.

\section{References}

1. Curtis RE, Travis LB, Rowlings PA, et al. Risk of lymphoproliferative disorders after bone marrow transplantation: a multiinstitutional study. Blood 94: 2208-2216, 1999.

2. Bacigalupo A. Antilymphocyte/thymocyte globulin for graft versus host disease prophylaxis: efficacy and side effects. Bone Marrow Transplant 35: 225-231, 2005.

3. Cohen J, Gandhi M, Naik P, et al. Increased incidence of EBVrelated disease following paediatric stem cell transplantation with reduced-intensity conditioning. $\mathrm{Br} \mathrm{J}$ Haematol 129: 229-239, 2005.

4. Ocheni S, Kroeger N, Zabelina T, et al. EBV reactivation and post transplant lymphoproliferative disorders following allogeneic SCT. Bone Marrow Transplant 42: 181-186, 2008.

5. van Esser JW, van der Holt B, Meijer E, et al. Epstein-Barr virus $(\mathrm{EBV})$ reactivation is a frequent event after allogeneic stem cell transplantation (SCT) and quantitatively predicts EBVlymphoproliferative disease following T-cell-depleted SCT. Blood 98: 972-978, 2001.

6. van Esser JW, Niesters HG, van der Holt B, et al. Prevention of Epstein-Barr virus-lymphoproliferative disease by molecular monitoring and preemptive rituximab in high-risk patients after allogeneic stem cell transplantation. Blood 99: 4364-4369, 2002.

7. Weinstock DM, Ambrossi GG, Brennan C, Kiehn TE, Jakubowski A. Preemptive diagnosis and treatment of Epstein-Barr virusassociated post transplant lymphoproliferative disorder after hematopoietic stem cell transplant: an approach in development. Bone
Marrow Transplant 37: 539-546, 2006.

8. Kuehnle I, Huls MH, Liu Z, et al. CD20 monoclonal antibody (rituximab) for therapy of Epstein-Barr virus lymphoma after hemopoietic stem-cell transplantation. Blood 95: 1502-1505, 2000.

9. Milpied N, Vasseur B, Parquet N, et al. Humanized anti-CD20 monoclonal antibody (Rituximab) in post transplant Blymphoproliferative disorder: a retrospective analysis on 32 patients. Ann Oncol 11 (Suppl 1): 113-116, 2000.

10. Faye A, Quartier P, Reguerre Y, et al. Chimaeric anti-CD20 monoclonal antibody (rituximab) in post-transplant B-lymphoproliferative disorder following stem cell transplantation in children. Br J Haematol 115: 112-118, 2001.

11. Brunstein CG, Weisdorf DJ, DeFor T, et al. Marked increased risk of Epstein-Barr virus-related complications with the addition of antithymocyte globulin to a nonmyeloablative conditioning prior to unrelated umbilical cord blood transplantation. Blood 108: 2874-2880, 2006.

12. Meijer E, Cornelissen JJ. Epstein-Barr virus-associated lymphoproliferative disease after allogeneic haematopoietic stem cell transplantation: molecular monitoring and early treatment of highrisk patients. Curr Opin Hematol 15: 576-585, 2008.

13. Ahmad I, Cau NV, Kwan J, et al. Preemptive management of Epstein-Barr virus reactivation after hematopoietic stem-cell transplantation. Transplantation 87: 1240-1245, 2009.

14. Faraci M, Caviglia I, Morreale G, et al. Viral-load and Blymphocyte monitoring of EBV reactivation after allogeneic he- 
Inter Med 49: 931-935, 2010 DOI: 10.2169/internalmedicine.49.3114

mopoietic SCT in children. In: Bone Marrow Transplantation Ad-

vance Online Publication. 26 October 2009; doi: 10.1038/

bmt.2009.302.

(C) 2010 The Japanese Society of Internal Medicine

http://www.naika.or.jp/imindex.html 